\title{
Islam Nusantara
}

DOI 10.18196/AIIJIS.2018.0091.267-270

\section{MUHAM MAD FAJ RI}

Universitas Muhammadiyah Yogyakarta

$\begin{array}{ll}\text { Judul } & \text { : Islam Nusantara } \\ \text { Penulis } & \text { : A hmad Sahal } \\ \text { Penerbit } & : \text { M izan Pustaka } \\ \text { Kota } & : \text { Bandung } \\ \text { Tahun } & : 2016 \\ \text { H alaman } & : 339 \\ \text { ISBN } & : 978-979-433-895-7\end{array}$

Buku Islam Nusantara ditulis oleh Ahmad Sahal adalah seorang aktivis dari organisasi Nahdlatul Ulama (NU) yang pernah menempuh studi doktoral di Amerika Serikat. Buku ini menuliskan landasan-landasan terbentuknya pergerakan Islam Nusantara yang digagas oleh NU dan merangkum pendapat pendapat dari sang tokoh seperti KH Mustafa Bisri (Gus Mus), KH Abdurrahman Wahid (Gusdur), Abdul Muqsith Ghazali, KH Said Aqil Siradj, Din Syamsuddin, dan Lukman Hakim Syaifuddin.

Pada bagian awal, Ahmad Sahal memaparkan sebuah prolog yang menceritakan awal potensi sebuah permasalahan di masa mendatang yang mungkin mendasari awal terjadinya ijtihad. Dimana ada sebuah hadist yang menceritakan tatkala mengutus $\mathrm{Mu}$ 'adz bin Jabal sebagai qadli (hakim) di Yaman, Rasulullah sempat bertanya kepadanya. Rasul bertanya, "Apabila dihadapkan padamu satu kasus hukum, bagaimana kamu memutuskannya?" Mu'adz menjawab, "Saya akan memutuskan berdasar Kitabullah. Nabi bertanya lagi, "Bila tidak kau temukan di Kitabullah? Balas Mu'adz, "Saya akan berhukum dengan Sunnah Rasul. Nabi melanjutkan pertanyaannya, "Bagaimana jika tidak kau temukan di Kitabullah maupun di Sunnah Rasulullah? Mu'adz menjawab, "Saya akan berijtihad berdasar pendapatku sendiri dengan sungguh-sungguh." Nabi lalu menepuk dada 
Mu'adz sebagai isyarat memberikan restu kepadanya.

Hal ini sebagai isyarat bahwa nabi mengiyakan berbagai permasalahan yang akan dihadapi oleh umatnya sepeninggalnya kelak. Bisa dilihat bahwa Yaman saja yang ketika saat itu masih satu negeri dengan Jazirah Arab dan semasa dengan Rasulullah sudah dimaklumi Nabi adanya berbagai masalah umat yang beragam, apalagi di Indonesia yang saat ini letaknya terpaut jarak dan waktu yang sangat jauh. Bisa dilakukan ljtihad sebagai upaya terakhir memecahkan permasalahan yang beragam dengan tidak meninggalkan kaidah merujuk pada al-Qur'an dan Sunnah.

Penulis menyampaikan latar belakang masalah yang mendorong ide terbentuknya pergerakan Islam Nusantara, dalam hal ini penulis memaparkan permasalahan ini sudah ada pada tahun 1980 an tentang penentuan kebijakan. Latar belakang yang mendasari terbentuknya gerakan Islam Nusantara sendiri juga berawal dari keresahan petinggi NU dan cendikiawannya terhadap masalah di tubuh NU itu sendiri, NU yang menggunakan metode Bahtul Masail untuk mendiskusikan masalah yang perlu dipecahkan. Tidak adanya perbedaan kasta ilmu di dalam sebuah bahtul masa'il membuat suasana forum bahtul masa'il menjadi terbuka menerima setiap pendapat. Namun penulis menyebutkan bahwa sebenarnya Bahtul Masa'il NU juga masih banyak memiliki kekurangan, para kyai yang seharusnya menjadi panutan tidak memiliki referensi yang cukup untuk dibawa ke ranah forum Bahtul Masa'il. Para kyai dan ustadz hanya membawa referensi yang berkutat pada 4 madzab saja. M ereka masih fanatik terhadap Madzhab Syafii dan referensi yang dipakai pun mengerucut kepada referensi dari Imam Syafi'i. Ketika dihadapkan dengan referensi yang pokok isinya bertentangan dengan kebiasaan mereka, seperti dari Ibnu Taimiyah dan Ibnu Qayyim al-Jauziyah, maka para kyai dan ustadz tidak akan memakainya sebagai referensi atau pembanding dalam memecahkan masalah didalam forum Bahtul M asa'il.

Alih-alih menjadikan forum Bahtul Masa'il sebagai medium memecahkan permasalahan dengan memperhatikan kaidah Ahlus Sunnah Waljama'ah yang berpikiran terbuka, forum ini malah menyisakan masalah. Yakni, masalah fanatisme madzab tertentu dan masih mengikuti kebiasaan lama tanpa pengetahuan atas dasar dan dalilnya.

Penulis juga memaparkan bagaimana awal masuknya Islam yang diprakarsai oleh Walisongo. Para wali mengenalkan agama Islam kepada masyarakat Hindu-Buddha yang memegang adat istiadat secara kental 
dan juga kepada masyarakat yang pada saat itu menganut Animisme dan Dinamisme. Para walisongo tidak lantas menjelaskan Islam dengan menabrak tradisi yang sudah ada. Mereka mengenalkan Islam dengan cara akulturasi, masuk di tengah tengah masyarakat dan mengikuti budaya yang ada di sana, lalu sedikit demi sedikit mengenalkan Islam dengan cara yang tidak disadari oleh masyarakat setempat. Sunan Kalijaga, misalnya, mengenalkan Islam dan cara bertuhan melalui cerit-cerita pewayangan. Sehingga, pada akhirnya, masyarakat sedikit demi sedikit mengetahui apa itu Islam dan tertarik memeluk Islam.

Sementara itu, Sunan Kudus adalah seorang ulama yang memiliki keahlian dalam merancang sebuah bangunan. Sunan Kudus yang selain memiliki peran utama sebagai pendakwah beliau juga memberikan kontribusi keahliannya tersebut kepada masyarakat. Beliau merancang sebuah masjid dengan tetap menampakkan simbol simbol Hindu-Buddha di pancuran wudhu dan menara pada masjid Kudus, bukan dengan merancang masjid yang menjadi ciri khas masjid di Timur Tengah. Sikap dan tindakan berdakwah yang dilakukan para Walisongo tersebut semata mata untuk menyampaikan dakwah namun masih bisa menyesuaikan dengan budaya masyarakat Indonesia pada waktu itu. Ini sebagai bukti Islam Nusantara sebagai representasi dari Islam yang rahmatan lil'alamiin. Bisa kita bayangkan bagaimana jika dahulu Walisongo berdakwah dengan memaksakan Islamn yang formal, barangkali umat Islam Indonesia tidak sebanyak seperti sekarang ini. Kita bisa lihat sampai sekarang ini dimana Timur Tengah masih merasakan gejolak konflik tak berujung, Islam Nusantara hadir dengan tidak memaksakan Islam yang formal, namun membaur terhadap budaya masyarakat setempat dan sedikit demi sedikit menyampaikan ajaran Islam.

Dari paparan di atas, Ahmad Sahal mencoba menyanggah orang-orang yang menganggap gerakan Islam Nusantara adalah upaya untuk memindahkan kiblat umat Indonesia ke Nusantara. Ini bukan berarti adanya Islam Nusantara menjadi berbeda dengan adanya Islam M alaysia, Islam Vietnam, dan sejenisnya. Ini hanyalah pergerakan pendakwahan dari representasi Islam yang Rahmatan lil'alamin agar lebih bisa diterima oleh manusia yang belum mengenal Islam. Buku yang ditulis oleh Ahmad Sahal ini mengajak pembaca agar bisa menyampaikan nilai-nilai keislaman dengan yang damai, tanpa ada pemaksaan apalagi dengan kekerasan dan pentakfiran. 


\section{$270 \mid$ seraum}

Bagian yang terbaik dari buku ini adalah penjelasan bahwa agama Islam selain bersifat ilahiah, juga bersifat Islam bersifat insaniah. Artinya, Islam juga merasuk pada sekumpulan manusia yang memiliki kebudayaan berbeda-beda. Islam juga bersifat wasathiyah yang berarti moderat dan memiliki beberapa makna yang salah satu maknanya adalah al-waqi'iyyah (realistis). Realistis di sini berarti mengetahui dan mengakui keadaan asli masyarakat, namun tidak menyerah untuk menyampaikan kebenaran yang ideal.

Pada halaman 171 Ahmad Sahal menyebutkan istilah Islam SalafiWahabi untuk menyebutkan kelompok yang dianggapnya terlalu kering dalam berdakwah dan tidak cocok jika berdakwah pada kaum M uslimin Nusantara. Nampaknya apa yang disebutkan Ahmad Sahal dan semua anggapan tersebut hanya mewakili pendapat NU saja dan tidak menunjukkan realitas yang sebenarnya. A palagi penggunaan kata Salafi-Wahabi ini terlalu simplistik untuk mendeskripsikan keadaan sebenarnya komunitas Salafi, baik yang di Indonesia maupun di Kerajaan Arab Saudi. Pada realitasnya, kata Wahabi itu disematkan untuk kaum yang memberontak di Jazirah Arab pada masa silam dan juga mempunyai nuansa dan kompleksitasnya tersendiri.

Buku dengan tema Islam Nusantara sebenarnya sudah banyak terbit semenjak dekade terakhir, dan buku "Islam Nusantara" karya Ahmad Sahal ini juga bukanlah yang terbaru. Namun buku Ahmad Sahal adalah pioner dan bisa menggambarkan dengan jelas apa itu Islam Nusantara.** 
